\title{
The Effect of HHO and Biodiesel Blends on Performance and Emission of Diesel Engine-A Review
}

\author{
K. A. Kale* and M. R. Dahake \\ Mechanical Engineering Department, AISSMS's Collage of Engineering, Savitribai Phule Pune University, India
}

Accepted 15 June 2016, Available online 20 June 2016, Special Issue-5 (June 2016)

\begin{abstract}
The continuous increasing demand for energy and the decreasing petroleum resources has led to the search for alternative fuels which is renewable and sustainable. In search of alternative fuels for CI engines, many experimental studies have been carried out. This paper presents a comprehensive review on the performance and emissions of compression ignition engine using HHO and biodiesel as alternate fuel or supplement to diesel fuel. The properties of HHO and biodiesel have also been described. The experimental setup used by different researchers for the evaluation and their results regarding performance and emission with respect to diesel have been presented for several studies. The overall impression is that the performance of the engine is improved with use of HHO and biodiesel and environmental aspects are significantly improved.
\end{abstract}

Keywords: Hydroxy gas, Biodiesel, Diesel Engine, Emissions

\section{Introduction}

Increasing environmental pollution and depletion of fossil fuels have necessitated a strong interest in the research for alternative fuel sources. Air pollution is not only considered a nuisance, but also a threat to public health. Use of fossil fuel leads to various issues like environmental degradation and health problems such as nausea, headaches, impairment of lung function and eye, nose and throat irritations, also affects the respiratory system. In total, air pollution has human health impacts, increases the cost of living and hurts economy and environment. Conventional petroleum based fuels have limited resources. Other problem is day by day increase of fuel price due to the scarcity of petroleum products. Also, environmental concerns have motivational legislative actions by government around world to reduce emission and improve fuel economy . When fossil fuels are burned, a lot of carbon dioxide is released. Carbon dioxide is a gas that absorbs heat and contributes towards the greenhouse effect. Another gas released when fossil fuel is burned sulfur dioxide which combines with water in the atmosphere to form sulfuric acid. This leads to acid rain which alters the normal $\mathrm{pH}$ of soil that supports plant growth. Hence, engine manufacturer and researchers worldwide are currently encouraging to find out an alternative approaches to increase fuel economy and to reduce harmful emissions from internal combustion engines.
In this paper, the contemporary research on the use of hydrogen and biodiesel for diesel engine is given. First hydrogen as an alternate fuel and then biodiesel with various blends are discussed by surveying existing literature.

\section{Hydroxy (HHO) Gas}

Hydrogen/ HHO is a kind of green renewable fuel, and its combustion products are mainly water and $\mathrm{NO}_{\mathrm{X}}$ emission [3]. HHO has outstanding advantages compared to other alternative fuels since it is carbon free fuel, which results in total elimination of $\mathrm{HC}, \mathrm{CO}$ and $\mathrm{CO}_{2}$ emissions. Hydrogen/ $\mathrm{HHO}$ can be used in a diesel engine with or without modifications in the engine. Various methods are used for hydrogen induction such as by carburation, manifold or port injection and in-cylinder injection. The heating value of HHO is much higher than that of conventional fuel. It is a non-toxic, non- odorant gas and also can be burn completely. Hydrogen has a high auto ignition temperature and wide flammability range making it suitable for high compression lean burn engines. Also a high flame speed prevents engine knock. Hydrogen has the ability to burn at extremely lean equivalence ratios. It will burn at mixtures seven times leaner than gasoline and five times leaner than methane. Efficiencies are also improved because hydrogen has a very small gap quenching distance allowing fuel to burn more completely. The only drawback of hydrogen is that even though its lower heat value is greater than other hydrocarbon fuels, it is less dense. 
Therefore a volume of hydrogen contains less energy. Hydroxy (HHO) gas is mixture of hydrogen and oxygen particles at 2:1 ratio.

To store on- board in forms of a compressed gas, a cryogenic liquid or a gas dissolved in metal hydrides, a large amount of hydrogen is required to be stored and carried which leads to increase in overall weight of the vehicle. Onboard generation of hydrogen/ HHO can be better option for transport vehicles to eliminate the problems related with storage.

Electrolysis is the most common process used to split $\mathrm{H}_{2}$ from water by a unique electrode design. The electrode stack consists of two types of electrodes comprising anode and cathode. In the electrolyser anode and cathode are placed sequentially with a gap of $2 \mathrm{~mm}$ between them. HHO gas production primarily depends on the gap between the electrodes and also directly proportional to the surface area of the anode and cathode electrodes, concentration of aqueous solution and potential difference applied between the anode and cathode electrodes. When an electrical potential is applied across the electrodes of the electrolyser, water gets directly transmitted into $\mathrm{HHO}$ gas and is collected in gas collection chamber and then delivered through flexible hose to the intake manifold of the engine.

The properties of hydrogen and diesel are given in Table 1.

Table 1: Properties of Diesel and hydrogen

\begin{tabular}{|c|c|c|c|}
\hline Sr. No. & Properties & Diesel & Hydrogen \\
\hline 1 & $\begin{array}{c}\text { Auto ignition temperature } \\
(\mathrm{K})\end{array}$ & 530 & 858 \\
\hline 2 & $\begin{array}{c}\text { Minimum ignition energy } \\
(\mathrm{m})\end{array}$ & - & 0.02 \\
\hline 3 & $\begin{array}{c}\text { Flammability limits (volume } \\
\text { \% in air) }\end{array}$ & $0.7-5$ & $4-75$ \\
\hline 4 & $\begin{array}{c}\text { Stoichiometric air fuel ratio } \\
\text { on mass basis }\end{array}$ & 14.5 & 34.5 \\
\hline 5 & $\begin{array}{c}\text { Density at 16 }{ }^{0} \mathrm{C} \text { and } 1.01 \text { bar } \\
(\mathrm{kg} / \mathrm{m} 3)\end{array}$ & $\begin{array}{c}833- \\
881\end{array}$ & 0.0838 \\
\hline 6 & Net heating value (MJ/kg) & 42.5 & 119.93 \\
\hline 7 & Flame Velocity (cm/s) & 30 & $265-325$ \\
\hline 8 & Quenching gap in NTP air \\
$(\mathrm{cm})$ & - & 0.064 \\
\hline 9 & Diffusivity in air(cm $\left.{ }^{2} / \mathrm{s}\right)$ & - & 0.63 \\
\hline 10 & Research Octane number & 30 & 130 \\
\hline
\end{tabular}

The use of $\mathrm{HHO}$ as supplement to diesel has been investigated in several studies. Taun Le Anh, et al. have experimented effect of addition of HHO gas into SI engine intake manifold and reported an improved engine performance and decreased fuel consumption after enrichment of $\mathrm{HHO}$ gas. Also presented that $\mathrm{HC}$ emission was reduced, however $\mathrm{NO}_{\mathrm{X}}$ emission was increased. In literature, some of researchers used pure hydrogen and others experimented with hydroxy (HHO) gas produced by water electrolysis. N. Sarvanan, et al. studied on an experimental investigation on port injection of hydrogen with various hydrogen flow rates in diesel engine. The injection timing and injection duration for hydrogen were varied by the use of electronic control unit (ECU). The optimum hydrogen flow rate was found to be $7.5 \mathrm{lpm}$. The test results showed that the brake thermal efficiency for dual fuel operation increased by $15 \%$ compared to diesel fuel at $75 \%$ load. CO, CO2 emissions were lesser.

M. R. Dahake, et al. evaluated performance and emissions of diesel engine on addition of HHO gas at compression ratio of 18 and constant speed at 1500 rpm and varying load conditions. They reported that thermal efficiency was increased by $9.5 \%$ and specific fuel consumption was reduced by $15 \%$ at full load. Also $\mathrm{HC}$ and $\mathrm{CO}$ emissions were lesser at an average of $33 \%$ and $23 \%$ respectively. Bari, et al. carried out their experimental work with the use of $\mathrm{H}_{2} / \mathrm{O}_{2}$ produced by electrolysis under constant speed.

Results showed that the brake thermal efficiency increased by $2.6 \%$ at $19 \mathrm{~kW}, 2.9 \%$ at $22 \mathrm{~kW}$ and $1.6 \%$ at $28 \mathrm{~kW}$ and brake specific fuel consumption reduced by $7.3 \%, 8.1 \%$ and $4.8 \%$ at $19 \mathrm{~kW}, 22 \mathrm{~kW}$ and $28 \mathrm{~kW}$ respectively. The emissions of $\mathrm{HC}, \mathrm{CO}$ and $\mathrm{CO}_{2}$ were found to be reduced due to better combustion while increased $\mathrm{NO}_{\mathrm{X}}$ due to the higher temperature reached during combustion. To have a better idea about the variation of engine torque, specific fuel consumption, $\mathrm{CO}$ and $\mathrm{HC}$ emission of $\mathrm{CI}$ engine added with $\mathrm{HHO}$ gas, some of the results reported in literature are partially have been partially produced and presented in Figure $1,2,3$ and 4 . The effect of HHO addition on CI engine was studied by Kadir Aydin, et al. The results reported an increase in engine torque by an average of $19.1 \%$, reduction in $\mathrm{CO}$ and (HC) emissions and specific fuel consumption by averages of $13.5 \%, 5 \%$ and $14 \%$ respectively. Figure 1, 2 shows that the increment in engine torque is obtained with using HHO system compared to neat diesel operation. The increase in power and reduction in specific fuel consumption is due to better mixing of hydroxy gas with air and oxygen concentration of hydroxy leads to better combustion of fuel.

Since HHO gains a high flame speed and high flammability, addition of hydroxy would help fuel to be burned faster and more complete.

Figure 3 shows the variation in $\mathrm{HC}$ emission with engine speed. An average of reduction of $5 \%$ in $\mathrm{HC}$ emission is obtained as compared to pure diesel operation. As the hydroxy carbonless, burning of hydroxyl along with diesel leads to lower hydrocarbon levels and because of high cylinder temperature, the carbon particles present in lubricating oil and main fuel gets oxidized and converted into $\mathrm{CO}_{2}$. The short quenching distance and wide flammability range of hydroxy leads to less HC emission.

The variation in carbon monoxide (CO) emission with hydroxyl gas enrichment is shown in Figure 4. An average reduction of $13.5 \%$ is gained of $\mathrm{CO}$ emission. It is due to the absence of carbon in hydroxy gas. The HHO- diesel fuel burn more completely than pure diesel operation. 


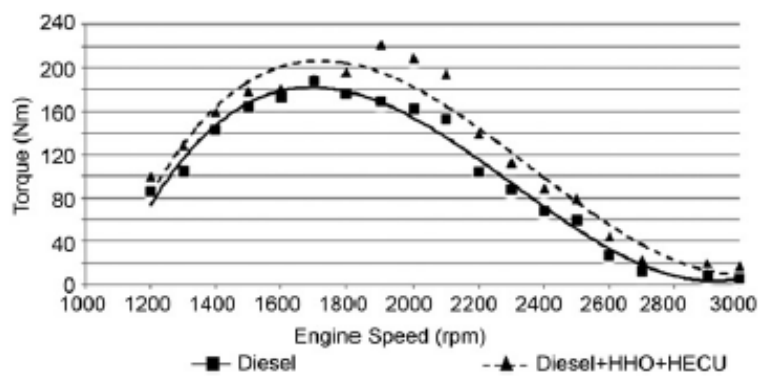

Figure 1: Variation of Engine Torque with Engine Speed

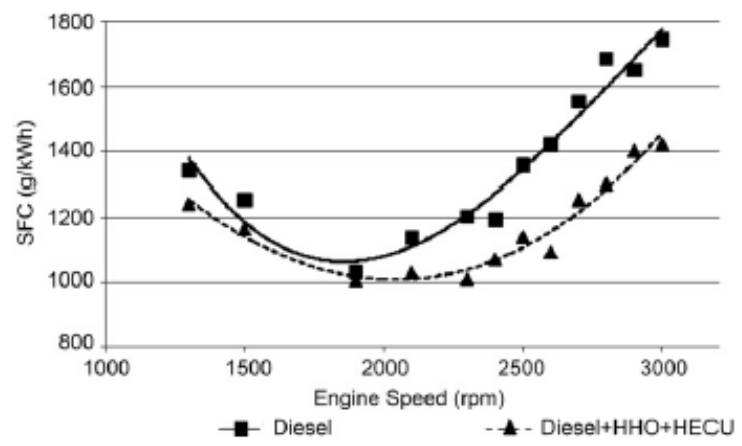

Figure 2: Variation of Specific fuel consumption with engine speed

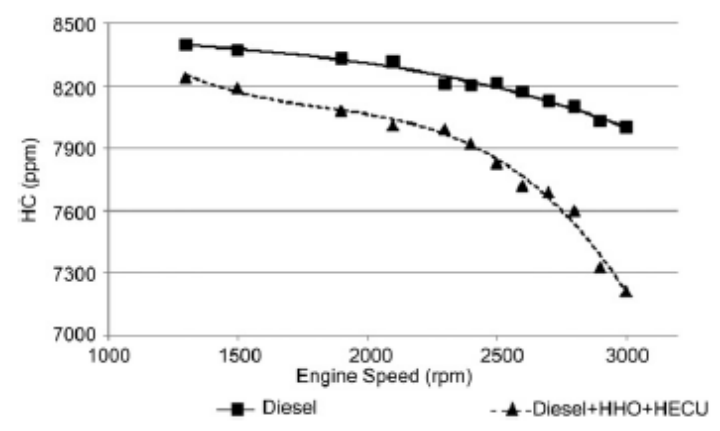

Figure 3: Variation of HC emission with speed

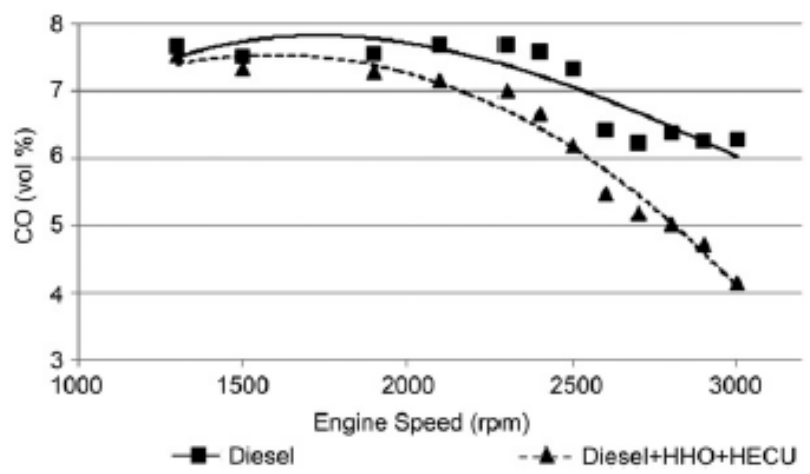

Figure 4: Variation of $\mathrm{CO}$ with engine speed

N. Saravanan, et al. experimented the combustion analysis using hydrogen with diesel and hydrogen with diethyl ether of diesel engine. They optimized timing for the injection of hydrogen was $5^{0} \mathrm{CA}$ before gas exchange top dead center and $40^{\circ}$ CA after gas exchange top dead center for hydrogen with diethyl ether. They concluded that brake thermal efficiency increased by $20 \%$ and $\mathrm{NO}_{\mathrm{x}}$ increased by $13 \%$ for hydrogen with diesel fuel. Hydrogen- diethyl ether operation showed a higher brake thermal efficiency of $30 \%$ with a significant reduction in $\mathrm{NO}_{\mathrm{x}}$ compared to diesel. S R Premkartikkumar, et al. produced HHO by the electrolysis process and injected along with intake air at the flow rate of $4.6 \mathrm{lpm}$. The results showed that the decreased fuel consumption and simultaneously engine-out pollutants came down by the addition of HHO with warm diesel fuel.

Mohamed M. EL- Kassaby, et al. constructed a simple innovative HHO generation system and evaluated the effect of HHO addition on the performance and emissions of a Skoda Felicia 1.3 GLXi gasoline engine. They concluded that $10 \%$ increment in thermal efficiency, $34 \%$ lesser fuel consumption and reduction in $\mathrm{CO}, \mathrm{HC}$ and $\mathrm{NO}_{\mathrm{x}}$ by $18 \%, 14 \%$ and $15 \%$ respectively. Ammar A. Al- Rousan, et al. designed fuel cell for HHO gas production, the generated HHO gas was injected into the air stream just before entering the carburetor of a Honda G 200 engine. The test results showed demonstrated that using $\mathrm{HHO}$ enhanced combustion efficiency, consequently reduced fuel consumption. Kang-Shin Chen, et al. investigated the effects of hydrogen and oxygen mixture $\mathrm{H}_{2} / \mathrm{O}_{2}$ on a heavy duty diesel engine using diesel and seven $\mathrm{H}_{2} / \mathrm{O}_{2}$ mixtures: 10-70 lpm, interval $10 \mathrm{lpm}$. They concluded that for $10-40 \mathrm{lpm}$ of $\mathrm{H}_{2} / \mathrm{O}_{2}$ mixture addition, the brake specific fuel consumption (BSFC) was higher than that of neat diesel. Due to improved combustion efficiency, the emission of hydrocarbon, carbon dioxide and carbon monoxide were all lowered, while those of the nitrogen oxides were increased. Radu Chiriac, et al investigated the efficiency, exhaust emissions and combustion characteristics of a tractor diesel engine, operating in dual fuel mode with HRG (hydrogen rich gas) gas aspirated in the induction air. They presented the results as the addition of HRG leads to a slight decrease of the brake thermal efficiency. NOx emission decreases with HRG addition at 40\% load and CO, CO2 emissions decreases continuously. The adverse impact on performance can be eliminated by correction of diesel fuel injection timing. C. Naresh, et al. produced the HHO gas by electrolysis process and compared the obtained results with neat diesel fuel. They found that mechanical efficiency, brake power, brake thermal efficiency, were increased for engine operating on $\mathrm{HHO}$ gas as compared to diesel. Emissions like $\mathrm{HC}, \mathrm{CO}, \mathrm{CO}_{2}$, NOx were greatly reduced.

\section{Biodiesel}

Biodiesel is the name of a clean burning alternative fuel, produced from domestic, renewable resources. It is simple to use, biodegradable, nontoxic, and free of sulfur. It is a valuable form of energy which can be used in a conventional engine directly or by blending with 
conventional fuel like diesel. It has high cetane number, low sulfur, low volatility and presence of oxygen in the fuel molecule. Another advantage of biodiesel fuel is that it can also be blended with other oils. Biodiesels are extracted from non edible and edible oils such as neem, sunflower, pongamia, jathropha, mahua, palm, sesame etc. The best way to use these oils as fuel is to convert it into biodiesel.

The main problem of using neat vegetable oils as fuel in diesel engines is its high viscosity which leads to the various problems in diesel engine such as; the blockage of fuel lines, filters, poor atomization of the fuel, incomplete combustion, severe engine deposits, piston ring sticking, gum formation and thickening of the lubricating oil, etc. To solve these problems, the usual methods adopted are blending in small blend ratios with normal diesel fuel, pre-heating, micro emulsification with methanol or ethanol, cracking and converting them into bio-diesel fuels. The blending method has the advantages of improving the use of vegetable oil fuel with minimal fuel processing and engine modification. Hence, mixing diesel fuel with vegetable oils with specific ratio reduces viscosity and consequently it can be used as alternative fuels in diesel engines.

Biodiesel refers to the pure fuel before blending with diesel fuel. Biodiesel blends are denoted as, "BXX" with "XX" representing the percentage of biodiesel contained in the blend (i.e.: B10 is $10 \%$ biodiesel, $90 \%$ petroleum diesel).

\subsection{Tranesterification Process}

Viscosity of neat vegetable oil is reduced by chemical process called tranestrification. In this process, the triglyceride present in the oil or fat reacts with alcohol (methanol or ethanol) in the presence of a catalyst which is alkalime in nature. A catalyst such as sodium or potassium hydroxide is required. Glycerol (also called glycerin) is produced as a by-product. The reaction temperature near the boiling point of the alcohol is recommended.

Nevertheless, the reaction may be carried out at room temperature. The reactions take place at low temperatures $\left(\sim 65^{\circ} \mathrm{C}\right)$. Bio-diesel is further purified by washing and evaporation to remove any remaining methanol.

Husamettin Bulut, et al. used a blend of $50 \%$ sesame oil and 50\% diesel fuel as an alternative fuel in a direct injection diesel engine. The experimental results showed that the engine power and torque of the mixture of sesame oil-diesel fuel are close to the values obtained from diesel fuel and the amounts of exhaust emissions are lower than those of diesel fuel.

Abdurrahman Saydut, et al. extracted sesame oil from the seeds of sesame. The methyl ester of sesame (Sesamum indicum L.) seed oil was prepared by transesterification of the crude oil. Transesterification shows improvement in fuel properties of sesame seed oil. The results showed that the production of biodiesel from sesame seed oil as a viable alternative to the diesel fuel. N. R. Banapurmath et al presented the results of investigations carried out on a singlecylinder, four-stroke CI engine operated with methyl esters of honge oil, jatropha oil and sesame oil. They investigated comparative measures of brake thermal efficiency, smoke opacity, $\mathrm{HC}, \mathrm{CO}, \mathrm{NO}_{\mathrm{x}}$, ignition delay, combustion duration and heat release rates. Reported Engine performance in terms of higher brake thermal efficiency and lower emissions of $\mathrm{HC}, \mathrm{CO}$ and $\mathrm{NO}_{\mathrm{X}}$ for sesame oil methyl ester operation compared to methyl esters of Honge and Jatropha oil operation.

M. A. Kalam et al. conducted the experiment with various palm and calophyllum inophyllum biodiesel blends (PB10, PB20, PB30, CIB10, CIB20 and CIB30) at a full load engine speed range of 1000-2400 rpm and compared results with neat diesel operation. They concluded that average brake specific fuel consumption increased for all blends of both biodiesel. Author reported that PB20 has better engine performance, lower emission compared with diesel and biodiesel blends. Daisuke Kawano et al [20] evaluated the exhaust emission from light-duty garbage trucks (fueled with biodiesel) and heavy-duty diesel buses during JEo5 mode tests and compared between biodiesel derived from waste cooking oil and diesel fuel. Results showed that CO, NHMC and unburned emissions were reduced and NOX was increased. Also PM emission reduced. A decrease in heating value of the fuel with biodiesel blending caused low fuel economy of both vehicles. Properties of diesel and biodiesel are shown in Table 2, 3, 4 .

D. B. Hulwan, et al. did experiment for three dieselethanol-biodiesel blends (ethanol content 20\%, 30\%, $40 \%$ by volume) on diesel engine. Results showed that more brake specific fuel consumption for DEB than diesel. Lower Brake thermal efficiency for DEB than diesel observed. CO and HC increased for DEB at low load. They concluded that use of DEB blends of high ethanol fraction in diesel engines with increasing in cylinder temperature by various methods such as high compression ratio and advanced injection timing.

J. Hemanandh, et al.studied the emission and performance of hydrotreated sunflower biodiesel (HTSF B25 and HTSF B100) at constant speed of 1500 rpm on diesel engine and made the comparison with neat diesel. Results showed that decrease in brake specific fuel consumption, $\mathrm{CO}, \mathrm{HC}, \mathrm{NO}_{\mathrm{X}}$ and increase in brake thermal efficiency. The results have been discussed here by Figure 5, 6, 8, 9 .

Figure 5 shows the brake specific fuel consumption (BSFC) of hydrtreated sunflower oil at different loads is compared with diesel. From graph it can be seen that the brake fuel consumption is decreased for HTSF B25 and HTSF B100 at full load condition compared with diesel.

Comparison of brake thermal efficiency for sunflower biodiesel and diesel is shown in Figure 6. It can be seen form graph that the brake thermal efficiency of biodiesel is greater than diesel. The brake 
thermal efficiency of HTSF B25 and HTSF B100 increases up to $10 \%$ and $38 \%$ compare with diesel. This is due to high calorific value and high cetane number of hydrotreated sunflower biodiesel.

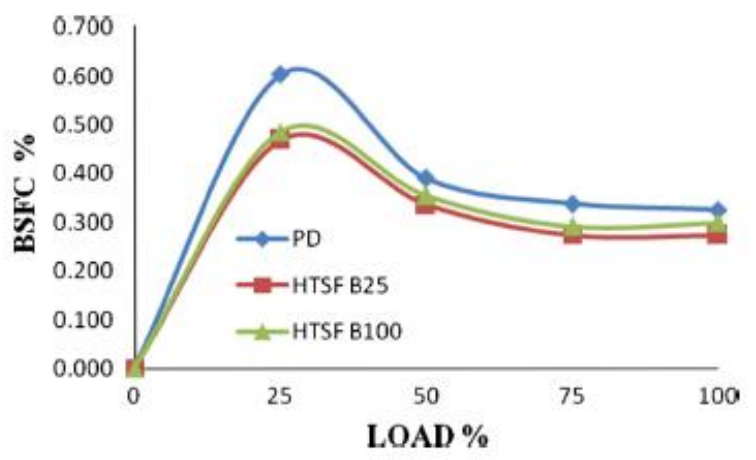

Figure 5: Comparison of BSFC emission for HTSF B25 and HTSF B100 with diesel

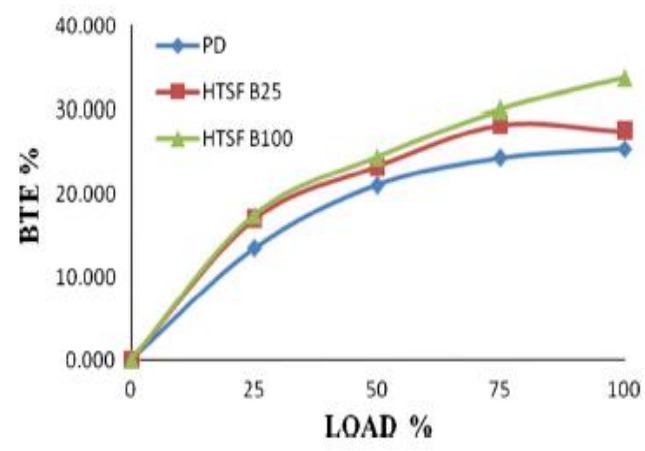

Figure 6: Comparison of Brake thermal efficiency for HTSF B25 and HTSF B100 with diesel

Figure 7 shows the comparison of HC emission of HTSF B25 and HTSF B100 with diesel. The HC emission reduces in HTSF B25 and HTSF B100 by 42\% and 55\% respectively. The blend was tested at full load condition and constant speed. The figure 8 shows comparison of CO emission for HTSF B25 and HTSF B100 with reference to diesel. From graph it can be observed that CO emission for HTSF B25 is same as diesel up to $75 \%$ of load and then decreases at full load. For HTSF B100, it is decreased by $37 \%$ at full load.

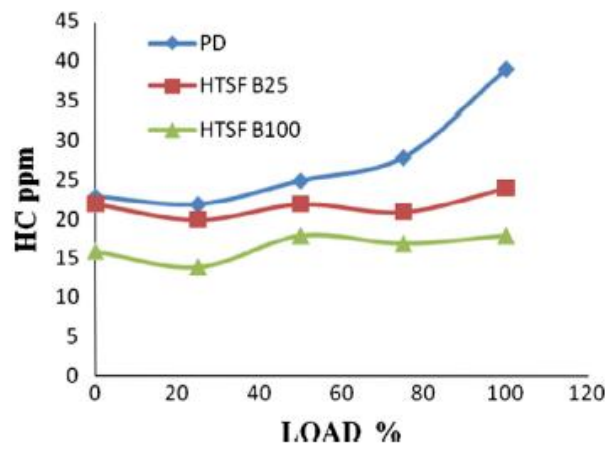

Figure 7: Comparison of HC emission for HTSF B25 and HTSF B100 with diesel
The figure 8 shows comparison of $\mathrm{CO}$ emission for HTSF B25 and HTSF B100 with reference to diesel. From graph it can be observed that $\mathrm{CO}$ emission for HTSF B25 is same as diesel up to $75 \%$ of load and then decreases at full load. For HTSF B100, it is decreased by $37 \%$ at full load.

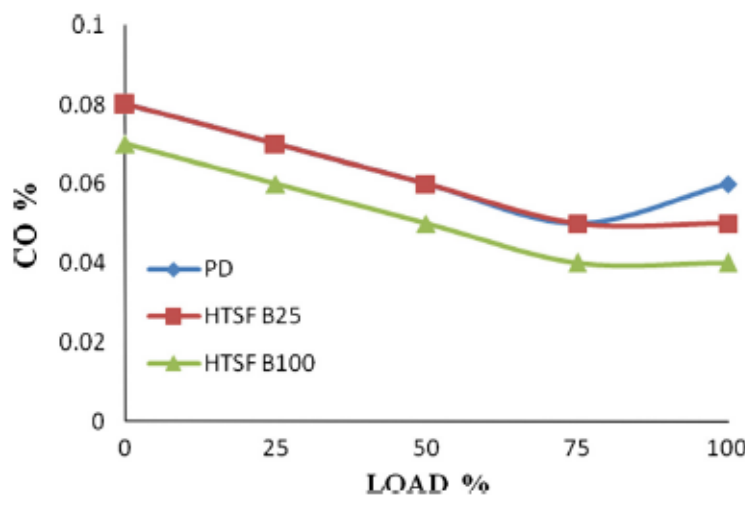

Figure 8: Comparison of CO emissions for HTSF B25 and HTSF B100 with diesel

Very few works have been done with the combination of two different biodiesel blends with diesel. K. Srithar, et al. [23] experimented two biodiesels from pongamia pinnata oil (karanj) and mustard oil and blended with diesel at various ratios. They did the experiment in single cylinder diesel engine at various loads with constant speed of 3000rpm. The results observed increase in brake thermal efficiency. The emissions of $\mathrm{HC}$ and $\mathrm{NO}_{\mathrm{X}}$ were higher than that of diesel.

Hwai Chtuan Ong, et al. investigated the engine performance and emission by jatrop curcas, ceiba pentnadra and calophyllum inophyllum biodiesel (10\%, $22 \%$ and $50 \%$ by volume) in CI engine at full load. They concluded that among all blending ratios for the three biodiesel blends, $10 \%$ biodiesel blend showed the best engine performance in terms of engine torque, engine power, fuel consumption and brake thermal efficiency.

Significant reduction in $\mathrm{CO}_{2}, \mathrm{CO}$ and smoke opacity with increase in $\mathrm{NO}_{x}$ emission for biodiesel blends was observed. J. Patterson, et al. [25] used three different biodiesels (rape, soy and waste oil) for engine performance and emission at five load conditions and two different speeds. Biodiesel blends such as S5, S50, S100, R5, R50, R100, and W5, W50 and W100 were compared with diesel. They concluded that in an unmodified engine, rape derivative fuel gave the best combustion and emission performance.

Table 2: Properties of Palm and Calophyllum Inophyllum biodiesel blend

\begin{tabular}{|c|c|c|c|c|c|c|}
\hline Property & Units & Diesel & PB10 & PB20 & CIB10 & CIB20 \\
\hline $\begin{array}{c}\text { Density at } \\
15^{\circ} \mathrm{C}\end{array}$ & $\mathrm{kg} / \mathrm{m}^{3}$ & 857.6 & 858.1 & 859.7 & 859.5 & 860.4 \\
\hline $\begin{array}{c}\text { Density at } \\
40^{\circ} \mathrm{C}\end{array}$ & $\mathrm{kg} / \mathrm{m}^{3}$ & 829.7 & 832.1 & 834.5 & 832.6 & 835.3 \\
\hline $\begin{array}{c}\text { Kinematic } \\
\text { Viscosity at }\end{array}$ & $\mathrm{mm}^{2} / \mathrm{s}$ & 3.493 & 3.362 & 3.459 & 3.732 & 3.799 \\
\hline
\end{tabular}

5| MIT College of Engineering, Pune, India, MECHPGCON 2016, INPRESSCO IJCET Special Issue-5 (June 2016) 


\begin{tabular}{|c|c|c|c|c|c|c|}
\hline $40^{\circ} \mathrm{C}$ & & & & & & \\
\hline $\begin{array}{c}\text { Viscosity } \\
\text { index }\end{array}$ & - & 132 & 139 & 147 & 135 & 138 \\
\hline Cetane index & - & 48.9 & 47.9 & 49.2 & 47.8 & 49.2 \\
\hline Cloud point & ${ }^{0} \mathrm{C}$ & 8 & 8 & 8 & 8 & 8 \\
\hline Flash point & ${ }^{0} \mathrm{C}$ & 68.5 & 76.5 & 77.3 & 72.3 & 73.1 \\
\hline Pour point & ${ }^{\circ} \mathrm{C}$ & 0 & 1 & 1 & 1 & 1 \\
\hline $\begin{array}{c}\text { Calorific } \\
\text { value }\end{array}$ & $\mathrm{MJ} / \mathrm{kg}$ & 45.6 & 44.27 & 43.75 & 44.48 & 43.86 \\
\hline
\end{tabular}

\begin{tabular}{|c|c|c|c|}
\hline Flash point & ${ }^{0} \mathrm{C}$ & 254.5 & 236.5 \\
\hline Pour point & ${ }^{0} \mathrm{C}$ & 9 & 8 \\
\hline Calorific value & $\mathrm{MJ} / \mathrm{kg}$ & 39.728 & 40.65 \\
\hline
\end{tabular}

PB10: $10 \%$ palm biodiesel with $90 \%$ diesel fuel, PB20\%: 20\% palm biodiesel with $80 \%$ diesel fuel, CIB10: $10 \%$ calophyllum inophyllum biodiesel with 90\% diesel fuel, CIB20: $20 \%$ calophyllum inophyllum biodiesel with $80 \%$ diesel fuel.

B. L. Maharana, et al. evaluated the performance of diesel engine fueled with palm biodiesel (B00, B10, B15, B20, B25, B30) and compared with nest diesel operation. Results obtained showed that thermal efficiency was slightly less and slightly higher specific consumption with biodiesel when compared pure diesel. Biswajit Paul, et al. used a dual biodiesel blend, mixtures of two different kinds of biodiesel namely palm and jatropha for evaluation in a diesel engine with varying loads. The results for lower blend biodiesel showed increased in brake power than diesel. Notable decrease in exhaust gas temperature for most biodiesel and average reductions in $\mathrm{CO}$ was observed when compared with diesel.

I. M. Rizwanul Fattah, et al. presented the investigation of the antioxidant addition effect on engine performance and emission. Calophyllum inophyllum biodiesel was used at constant load varying speed condition. Results showed that addition of antioxidants increased BP and reduced brake specific fuel consumption. Reduced $\mathrm{NO}_{\mathrm{x}}$ emission. They concluded as CIB20 blends with antioxidants can be used in diesel engine without modification. Obed M. Ali, et al.used palm biodiesel to evaluate engine performance test results. Results demonstrate that there was no statistically significant difference for engine brake thermal efficiency compared to diesel. Daisuke Kawano, et al. used rapeseed oil methyl ester (RME) as a biodiesel applied to multi cylinder light duty diesel engine. They reported that NMHC, CO and unburned emission was reduced but increased in $\mathrm{NO}_{\mathrm{x}}$. Biodiesel blending drastically reduced engine-out soot emission due to the oxygen content in biodiesel molecule.

Table 3: Properties of crude palm and calophyllum inophyllum oil

\begin{tabular}{|c|c|c|c|}
\hline Properties & Units & Palm & $\begin{array}{c}\text { Calophyllum } \\
\text { inophyllum }\end{array}$ \\
\hline Density at $40^{\circ} \mathrm{C}$ & $\mathrm{kg} / \mathrm{m}^{3}$ & 897.6 & 926.4 \\
\hline $\begin{array}{c}\text { Kinematic } \\
\text { Viscosity at } 40^{\circ} \\
\mathrm{C}\end{array}$ & $\mathrm{mm}^{2} / \mathrm{s}$ & 41.782 & 55.358 \\
\hline Viscosity index & - & 184.3 & 164.8 \\
\hline $\begin{array}{c}\text { Oxidation } \\
\text { stability }\end{array}$ & $\mathrm{h}$ & 0.09 & 0.24 \\
\hline Cloud point & ${ }^{0} \mathrm{C}$ & 8 & 8 \\
\hline
\end{tabular}

Nidal H. Abu-Hamdeh, et al. investigated performance and emissions of diesel engine operated on almond biodiesel and compared them to palm oil biodiesel and baseline diesel fuel. Various blends such as $0 \%, 10 \%$, $30 \%$ and $50 \%$ on volume basis were used. The results showed that almond biodiesel resulted in improved performance in terms of lower brake specific fuel consumption, higher thermal efficiency and higher gas temperature. Almond biodiesel resulted in $\mathrm{CO}$, and $\mathrm{NO}_{\mathrm{X}}$, unburned fuel emissions, etc. Di Yao, et al. [32] used pure diesel, pure biodiesel and two biodiesel blends $10 \%$ and $20 \%$ by volume and conducted the New European Driving cycle (NEDC) emission test carried out on a Euro 3 compliant diesel car. Results showed that pure biodiesel and biodiesel blends had decreasing effects on $\mathrm{CO}$ and $\mathrm{HC}$ emission. They concluded as for the purpose of reducing vehicle emissions by fuelling alternative fuels, $10 \%$ is recommended volumetric mixture ratio of biodiesel blend for the test diesel car.

S. Nagaraja, et al. presents the results of performance and emission test for preheated palm oil biodiesel (5\%, $10 \%, 15 \%$ and $20 \%$ on a volume basis) and compared with standard diesel. The results showed that increased brake power, lower exhaust gas temperature, decreased $\mathrm{CO}$ and $\mathrm{HC}$ emission. $\mathrm{CO} 2$ emission found to be higher than diesel.

Sudhir Ghai, et al. used sunflower biodiesel prepared by transesterification. Various blends of sunflower methyl ester were tested in four stroke diesel engine and engine performance results were compared with the data obtained from pure diesel fuel. Results showed that 1.5 to $4 \%$ increase in brake thermal efficiency with biodiesel blends. With biodiesel blends, significant reduction in emissions of hydrocarbons as well as smoke/ particulates was noticed. $\mathrm{NO}_{\mathrm{x}}$ emissions with biodiesel blends were observed to be somewhat higher as compared to diesel.

Table 4: Properties of diesel fuel and sunflower biodiesel blends

\begin{tabular}{|c|c|c|c|c|c|}
\hline Fuel Type & $\begin{array}{c}\text { C.V } \\
(\mathrm{kJ} / \mathrm{kg})\end{array}$ & $\begin{array}{c}\text { Kin } \\
\text { Visc. } \\
\text { cSt } \\
@^{0} 40^{\circ} \mathrm{C} \\
\end{array}$ & $\begin{array}{l}\text { Density } \\
@ 15^{0} \mathrm{C} \\
\left(\mathrm{kg} / \mathrm{m}^{3}\right)\end{array}$ & $\begin{array}{c}\text { Flash } \\
\text { Point } \\
\left({ }^{0} \mathrm{C}\right)\end{array}$ & $\begin{array}{c}\text { Fire } \\
\text { Point } \\
\left({ }^{\circ} \mathrm{C}\right)\end{array}$ \\
\hline B00/D100 & 43.5 & 2.6803 & 0.846 & 54 & 64 \\
\hline B25/D75 & 41.925 & 3.184 & 0.854 & 81 & 89.5 \\
\hline B30/D70 & 41.61 & 3.284 & 0.8556 & 94.5 & 101.5 \\
\hline B100/D0 & 37.2 & 4.693 & 0.878 & 191 & 197 \\
\hline
\end{tabular}

B100: $100 \%$ pure sunflower biodiesel, D100: Pure diesel fuel, B25: 25\% sunflower biodiesel+ 75\% diesel fuel, B30: 30\% sunflower biodiesel $+70 \%$ diesel fuel. 
Some of researchers experimented performance and emission by using HHO gas injected in intake manifold and biodiesel as an alternative fuel and compare the results with neat diesel operation. J. Allen Jeffrey, et al. compared the effectiveness of Oxygen enriched hydrogen-HHO gas addition on performance characteristics of a CI engine. In this, $\mathrm{HHO}$ gas is made to supplement with Neem oil ethyl ester (NOEE). The biodiesel prepared by transesterification process and was blended with diesel as B10, B20 and B30. HHO gas was produced by water electrolysis process. They concluded the results as there was a rise in brake thermal efficiency and lesser fuel consumption when HHO was added with biodiesel and increased NOx emission and lower $\mathrm{HC}$ and $\mathrm{CO}$ emission when HHO gas added with biodiesel.

Sankar. T used the karanj oil as an alternative fuel. He calculated the performance and emission levels for the different blend ratios. The blended ratios were $\mathrm{D} 100 \%, \mathrm{D}+\mathrm{HHO}, \mathrm{K} 100 \%, \mathrm{~K}+\mathrm{HHO}, \mathrm{K} 25 \%+\mathrm{D} 75 \%+$ $\mathrm{HHO}, \mathrm{K} 50 \%+\mathrm{D} 50 \%+\mathrm{HHO}$ and $\mathrm{K} 75 \%+\mathrm{D} 25 \%+\mathrm{HHO}$. The loading was increased from no load to $16 \mathrm{~kg}$. By the experiment, he recommended the fuel combination of $\mathrm{D} 75 \%+\mathrm{K} 25 \%+\mathrm{HHO}$ for the biodiesel purpose in future without any change in diesel engine. R. B. Durairaj, et.al. produced HHO gas by electrolysis process from water. This oxy-hydrogen gas has been preheated with help of waste heat recovered from automobile exhaust. They concluded that use of biodiesel in conventional engines result in substantial reduction in emission of unburned hydrocarbons, carbon monoxide and particulate. Also the preheating of the air improves thermal efficiency and reduces the vibration of the engine.

Mustafa Kaan Baltacioglu, et al compared performance and emission characteristics of a pilot injection diesel engine with the addition of alternative fuels like pure hydrogen, HHO and biodiesel. They have produced (sunflower) biodiesel and blended with 10\% with diesel fuel. The amount of Hydrogen fuel supplied to the engine was adjusted to constant $10 \mathrm{~L} / \mathrm{min}$ during the experiment. The engine performance values and exhaust emission values were investigated. They have concluded that engine performance values were increased with enriching the intake air with HHO than pure hydrogen compared to standard diesel fuel operating condition. For exhaust gas emissions, pure hydrogen provided better results than HHO. These results are discussed in detail with help of Figure 9, 10, $11,12$.

Figure 9 shows the Variation in brake power with respect to engine speed. Brake power of $\mathrm{HHO}+\mathrm{B} 10$ enrichment fuel was an average of $13 \%$ higher than neat diesel fuel at $1800 \mathrm{rpm}$. This is due that biodiesel contains certain amount of oxygen which helps a more complete combustion of the biodiesel than diesel.

Figure 10 shows the graph of brake specific fuel consumption versus engine speed. Brake specific fuel consumption were less than diesel due to high flame speed, wide flammability range and short quenching distance which ensure diesel fuel and biodiesel to be combusted completely which may produced reduced brake specific fuel consumption.

Variation in $\mathrm{CO}_{2}$ emission versus engine speed is shown in Figure 11. Average reduction in $\mathrm{CO} 2$ emissions for $\mathrm{HHO}+\mathrm{B} 10$ was $12 \%$. This is because of no carbon present in $\mathrm{HHO}$ gas.

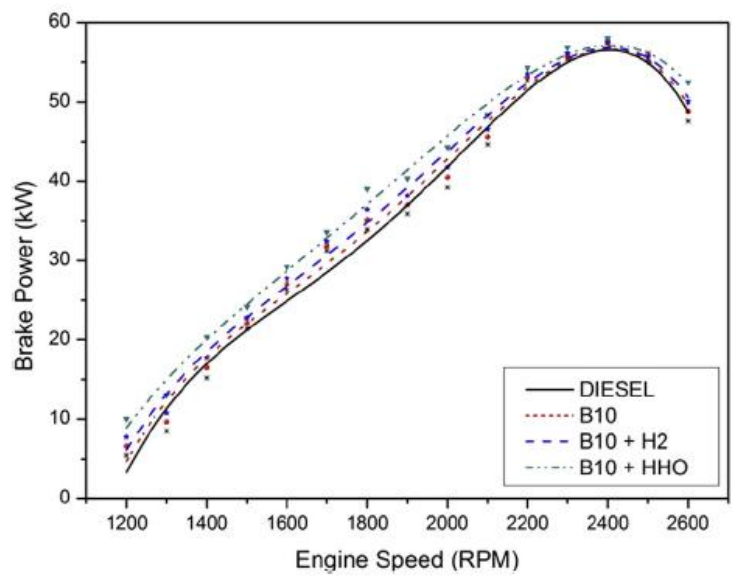

Figure 9: Brake Power versus Engine Speed

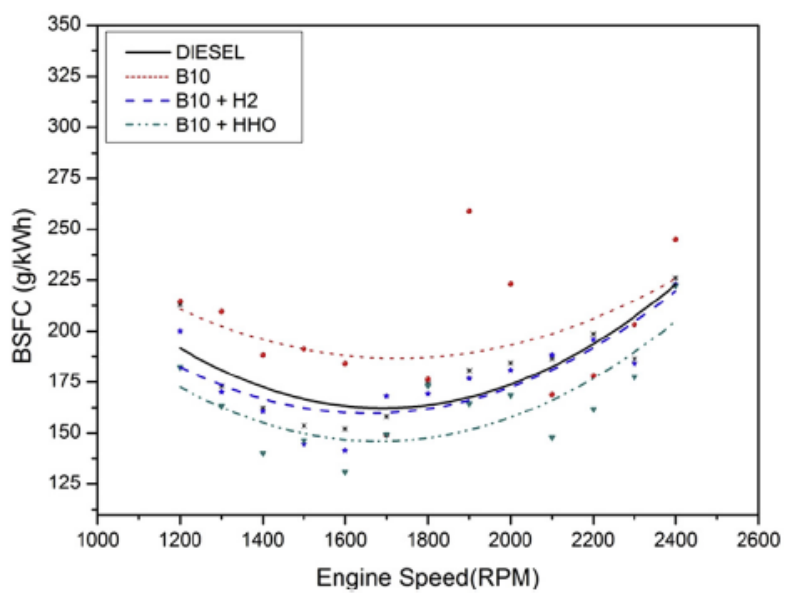

Figure 10: BSFC versus Engine Speed

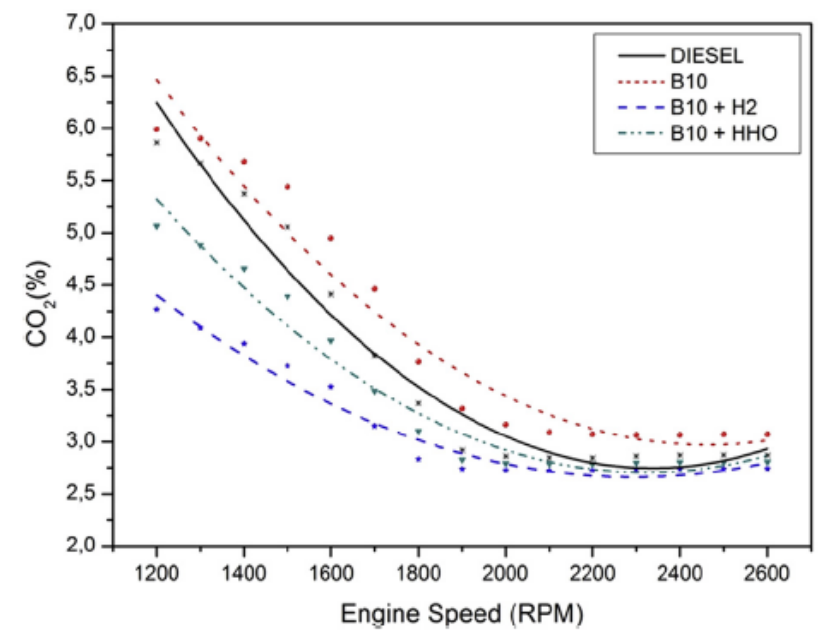

Figure 11: CO2 emission versus Engine Speed

Figure 12 shows the observations of lower CO emission for $\mathrm{HHO}+\mathrm{B} 10$ than diesel. Small quenching distance of 
HHO and higher oxygen content improves combustion in the cylinder. Absence of carbon in $\mathrm{HHO}$ is the reason for reduced $\mathrm{CO}$ emission.

M. Senthil Kumar, et al. evaluated the performance while using small quantities of hydrogen in a compression ignition engine primarily fuelled with namely jatropha oil. They designed a single cylinder water-cooled direct-injection diesel engine to develop a power output of $3: 7 \mathrm{~kW}$ at $1500 \mathrm{rev} / \mathrm{min}$ was tested at its rated speed under variable load conditions, with different quantities of hydrogen being inducted. The jatropha oil was injected into the engine in the conventional way. Results indicated an increase in the brake thermal efficiency. There was also a reduction in $\mathrm{HC}$ and $\mathrm{CO}$ emissions from 130 to $100 \mathrm{ppm}$ and $0.26-$ $0.17 \%$ by volume respectively at max. power output. With hydrogen induction, due to high combustion rates, NO level was increased from 735 to 875 ppm at full output.

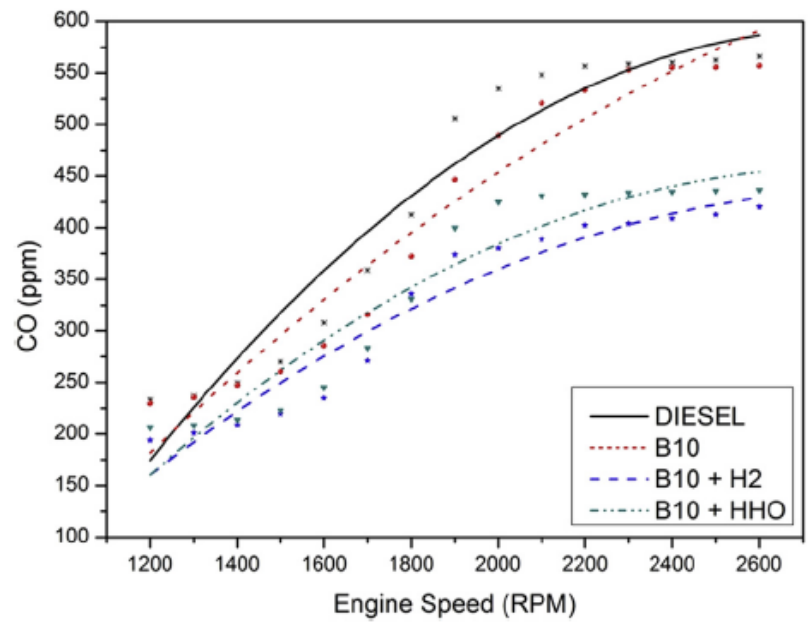

Figure 12: $\mathrm{CO}$ emission versus Engine Speed

\section{Conclusion}

Ongoing through the different experimentations performed by researchers worldwide and available literature, various aspects of $\mathrm{HHO}$ and biodiesel as $\mathrm{CI}$ engine fuel, the following conclusions have been drawn. HHO can be used in both the spark ignition and compression ignition engines with or without any modification. Also, biodiesel can be used in compression engines without any major modifications as sole fuel or dual fuel. The use of HHO, biodiesel and combination of both leads to higher the thermal efficiency, reduced specific fuel consumption and emissions. However, increase in oxides of nitrogen couldn't be prevented unless using some after treatment techniques.

\section{References}

Demshemino S. Innocent, (2013), Comparative analysis of biodiesel and petroleum diesel, International Journal of Education and Research, 1, 1-8.
J. Allen Jeffrey, (2014), A comparative study on performance and emission parameters of neem oil biodiesel blends and HHO supplementing neem oil biodiesel blend in a single cylinder compression ignition engine, International Journal of Science, Engineering and Technology Research, 3, 699704

Tuan Le Anh, (2013), Improving performance and reducing pollution emissions of a carburetor gasoline engine by adding HHO gas into intake manifold, SAE International,

N. Saravanan, (2010), Performance and emission studieson port injection of hydrogen with varied flow rates with diesel as an ignition source, Journal of Applied Energy, 87, 2218-2229.

M. R. Dahake, (2016), Effect of hydroxyl gas addition on performance and emission of diesel engine, International Journal of Science, Engineering and Technology Research, 3, 756- 760.

S. Bari, (2010), Effect of $\mathrm{H}_{2} / \mathrm{O}_{2}$ addition in increasing the thermal efficiency of a diesel engine, Journal of Fuel, 89, 378-383.

Kadir Aydin, (2010), Effect of hydroxyl (HHO) gas addiotn on performance and exhaust emissions in compression ignition engines, International Journal of Hydrogen Energy, 35, 11366- 11372.

N. Saravanan, (2008), Combustion analysis on a DI diesel engine with hydrogen in dual fuel mode, Journal of Fuel, 87, 3591- 3599.

SR. Premkartikkumar, (2013), Effect of addition of oxygen enriched hydrogen gas produces by electrochemical reaction in the reduction of pollutants coming out from a DI diesel engine, International Journal of ChemTech Research, 5, 1523- 1531.

Mohamed M. El- Kassaby, (2016), Effect of hydroxyl (HHO) gas on gasoline engine performance and emissions, Alexandria Engineering Journal, 55, 24- 251.

Ammar A. Al-Rousan, (2011), Effect of HHO gas on combustion emissions in gasoline engines, Journal of Fuel, 90, 3066-3070.

Kang-Shin Chen, (2012), Effect of regulated harmful matters from a heavy-duty diesel engine by $\mathrm{H}_{2} / \mathrm{O}_{2}$ addition to the combustion chamber, Journal of Fuel, 93, 524-527.

Radu Chiriac, et.al., (2011), The effect of HRG gas addition on diesel engine combustion characteristics and exhaust emissions, International Journal of Hydrogen Energy, 36, 12007-12014.

C. Naresh, (2014), Performance and exhaust gas analysis of a single cylinder diesel engine using $\mathrm{HHO}$ gas (Brown's gas), International Journal of Engineering Research, 3, 40- 47.

Ambarish Datta, (2016), A comprehensive review of biodiesel as an alternative fuel for compression ignition engine, Journal of Renewable and Sustainble Energy Reviews, 57, 799- 821.

Husamettin Bulut, (2008), The comparison of engine performance and exhaust emission characteristics of sesame oil- diesel fuel mixture with diesel fuel in a direct injection diesel engine", J. Renewable Energy, 33, 17911795,

Abdurrahman Saydut, (2008), Transesterified sesame (Sesamum indicum L.) seed oil as a biodiesel fuel, Journal of Bioresearch Technology, 99, 6656-6660.

N. R. Banapurmath, (2008), Performance end emission characteristics of a DI compression ignition engine operated on honge, jatropha and sesame oil methyl esters, Journal of Renewable Energy, 33, 1982- 1988.

M. A. Kalam, (2016), Optimization of performance, emission, friction and wear characteristics of palm and calophyllum inophyllum biodiesel blends, Journal of Energy Conservation Management, 118, 119- 134. 
Daisuke Kawano, (2010), Exhaust emission characteristics of commercial vehicles fuelled with biodiesel, $S A E$ International.

D. B. Hulwan, (2013), Study on emission reduction potential of diesel-ethanol-biodiesel blends of high ethanol fraction, SAE International.

J. Hemanandh, (2015), Emission and performance analysis of hydrotreated refined sunflower oil as alternate fuel, Alexandria Engineering Journal, 54, 389- 393.

K. Srithar, (2014), Experimental investigations on mixing of two biodiesels blended with diesel as alternative fuel for diesel engines, Journal of King Saud University- Engineering Sciences, 1-7.

Hwai Chyuan Ong, (2014), Engine performance and emissions using jatropha curcas, ceiba pentandra and calophyllum inophyllum biodiesel in a CI diesel engine, Journal of Energy, 69, 427- 445.

J. Patterson, (2006), Experimental study of DI engine performance using three different biodiesel fuels, $S A E$ International.

B. L. Maharana, (2015), Evaluation of performance of diesel engine with biodiesel, International Journal of Advanced Engineering Research and Studies, 181- 183.

Biswajit Paul, ( 2016), Comparison of performance and emission characteristics of DI CI engine fueled with dual biodiesel blends of palm and jatropha, Journal of Fuel, 173, 172- 179.

I. M. Rizwanul Fattah, (2104), Experimental investigation of performance and regulated emissions of a diesel with calophyllum inophyllum biodiesel blends accomplice by oxidation inhibotrs, Journal of Energy Conservation Management, 83, 232- 240.

Obed M. Ali, (2016), Analysis of blended fuel properties and engine performance with palm biodiesel- diesel blended fuel, Journal of Renewable Energy, 86, 59- 67.
Daisuke Kawano, (2008), Effect of biodiesel blending on emission characteristics of modern diesel engine, $S A E$ International.

Nidal H. Abu-Hamdeh, (2015), A comparative study of almond and palm oils as two biodiesel fuels for diesel engine in terms of emissions and performance, Journal of Fuel, 150, 318- 324

Di Yao, (2012), Laboratory investigation on emission characteristics of a diesel car fuelled with biodiesel blends, SAE International.

S. Nagaraja, (2015), Investigate the effect of compression ratio over the performance and emission of variable compression ratio engine fueled with preheated palm oildiesel blends, Procedia Earth and Planetary Science, 11, 393-401.

Sudhir Ghai, et al., (2008), Emissions and performance study with sunflower methyl ester as diesel engine fuel, ARPN Journal of Engineering and Applied Sciences, 3.

Sankar. T, (2014), The Effect of Oxy- Hydrogen (HHO) on the performance and emission characteristics of diesel and Karanj in single cylinder, four stroke diesel engine, Journal of Multidisciplinary Scientific Research, 2(1), 12-18.

R.B. Durairaj, (2012), HHO gas with biodiesel as a dual fuel with air preheating technology, Procedia Engineering, 38, 1112-1119.

Mustafa Kaan Baltacioglu, (2016), Experimental comparison of pure hydrogen and HHO (hydroxy) enriched biodiesel (B10) in a commercial diesel engine, International journal of hydrogen Energy, 30, 1-7.

M.Senthil Kumar, (2003), Use of hydrogen to enhance the performance a vegetable oil fuelled compression ignition engine, Int. J. Hydrogen Energy, 28, 1143-1154. 